\title{
The behaviour of $\mathrm{Eu}, \mathrm{Pu}, \mathrm{Am}$ radionuclide at burning radioactive graphite in an oxygen atmosphere. Computer experiments
}

\author{
T.S. Kolbin ${ }^{1}$, N.M. Barbin ${ }^{1,2, a}$, D.I. Terentev ${ }^{1}$ and S.G. Alekseev ${ }^{1}$ \\ ${ }^{1}$ Ural Institute of the State Fire Service Emergency Russia, Ekaterinburg, Russia \\ ${ }^{2}$ Ural Agrarian State University, Ekaterinburg, Russia
}

\begin{abstract}
Be means of the method of computer thermodynamic simulation we studied the behaviour of the europium, plutonium and americium from the combustion of radioactive graphite in oxygen. Europe is in the form of condensed $\mathrm{EuOCl}, \mathrm{Eu}_{2} \mathrm{O}_{3}$ and vapour $\mathrm{EuO}$. Pluto is in the form of condensed vapour $\mathrm{PuO}_{2}$ and $\mathrm{PuO}_{2}$. Americium is a condensed $\mathrm{AmO}_{2}, \mathrm{Am}_{2} \mathrm{O}_{3}$ and vapour Am. The basic reactions occurring compounds with europium, plutonium and americium. Equilibrium constants of the reactions have been determined.
\end{abstract}

\section{Introduction}

In connection with the completion of the operation and as a result of accidents and man-made emergencies, there are a large amount of radioactive graphite waste. Experts estimate that the total number of irradiated graphite in the world is about 250 thousand tonnes. Exactly reactor graphite is the most of the accumulated solid waste $[1,2]$.

In the Russian Federation there are about seventeen units. The weight of the graphite stack one reactor, depending on its type, is 1.5-2.5 thousand tonnes. The total mass of irradiated graphite in Russia is approximately equal to 60 thousand tonnes [3].

Technologies for waste disposal of nuclear energy, in the majority, based on the principle of isolation of radioactive graphite from the environment. Considered the most appropriate construction of underground storage in solid granite or basalt rocks. Such a method, by far, the safest, cheapest, and is used by many countries in the fifties of the twentieth century. However, this method also has a number of disadvantages, the main of which is the fact that the area for disposal not unlimited, and this disposal method does not require a reduction of waste [4].

Become a promising high-temperature treatment of radioactive waste. Today, there are several ways to burn radioactive graphite, oxidation air, oxygen, oxidation in molten alkali chlorides, carbonates $[2,5,6]$. The criterion for the successful development of the combustion process is acceptable emissions of radioactive elements to preserve the environment [7].

\footnotetext{
${ }^{a}$ Corresponding author: NMBarbin@mail.ru
}

This is an Open Access article distributed under the terms of the Creative Commons Attribution License 4.0, which permits unrestricted use, distribution, and reproduction in any medium, provided the original work is properly cited. 


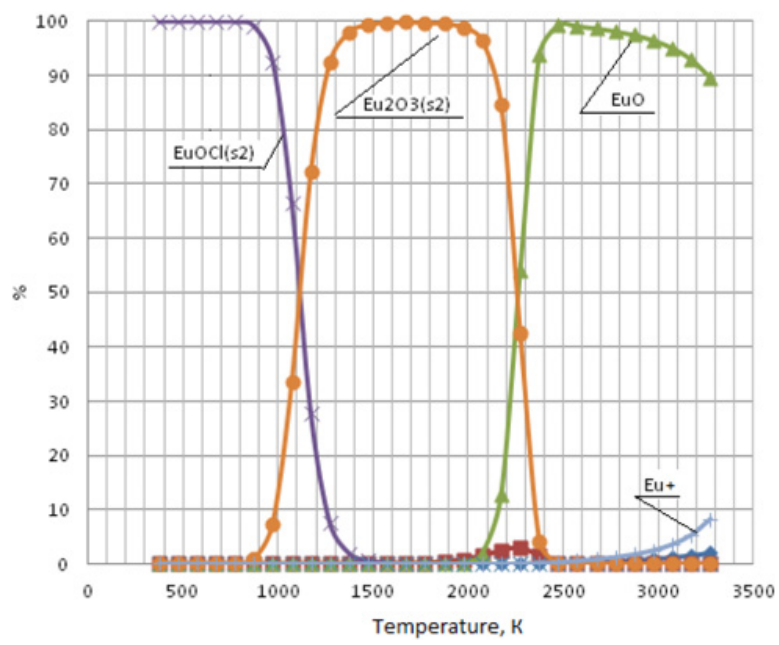

Figure 1. The distribution of Eu in the incineration of radioactive graphite.

Radioactive elements cannot be incinerated. Either they are part of a non-combustible waste, or evaporate, depending on their volatility. The gaseous components condense on the larger particles in the flue gases are removed scrub system [7].

\section{Objective}

The main objective of this study is the behaviour of some radioactive elements in combustion of the reactor graphite under oxygen.

\section{Computer experiment}

The behaviour of radioactive elements is not different from that of their non-radioactive isotopes. Studies conducted by thermodynamic modelling.

Thermodynamic modelling is a thermodynamic analysis of the equilibrium state of the system as a whole (complete thermodynamic analysis) [8,9]. Calculation methods are developed based on variation principles of thermodynamics.

One of the most advanced and efficient programs that implement such thermodynamic calculations is a software package TERRA, which is a step further development of the software package ASTRA $[10,11]$.

Calculations of the equilibrium phases and characteristics are carried out using the reference database on the properties of individual substances $[12,13]$.

\section{Results and discussion}

Fused $\mathrm{EuOCl}$ is predominant compound in the temperature range from 375 to $800 \mathrm{~K}$, then the quantity begins to decrease and reaches a value of $0 \mathrm{~mol} . \%$ At $1500 \mathrm{~K}$. The increase in the number of condensed $\mathrm{Eu}_{2} \mathrm{O}_{3}$ observed in the temperature range $900-1300 \mathrm{~K}$, and the reduction $1800-2500 \mathrm{~K}$. The growth of gaseous EuO happening to $2000 \mathrm{~K}$ at $2500 \mathrm{~K}$. On further heating to $3300 \mathrm{~K}$, the reduction in the amount of vapour $\mathrm{EuO}$ (with 99 mol.\% to 89 mol.\%) with a simultaneous increase in the amount of ions $\mathrm{Eu}+$ (8 mol.\%) and vaporous $\mathrm{Eu}(2 \mathrm{~mol} . \%)$. 


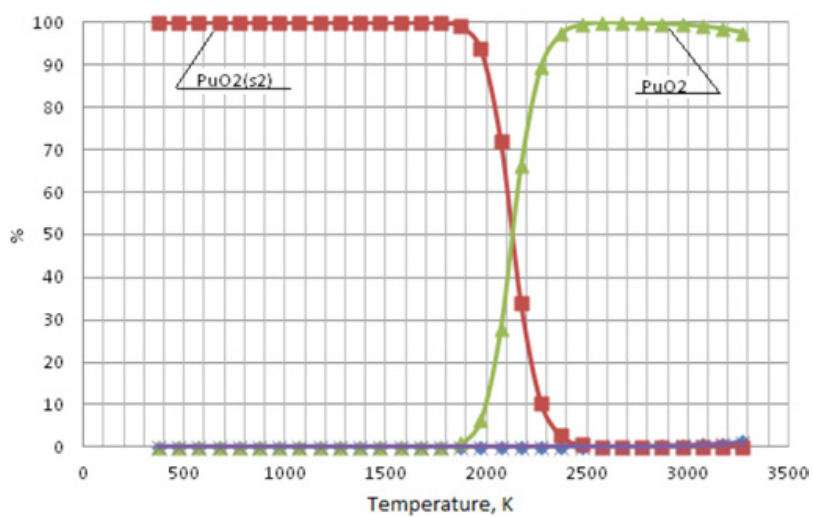

Figure 2. The distribution of $\mathrm{Pu}$ in the incineration of radioactive graphite.

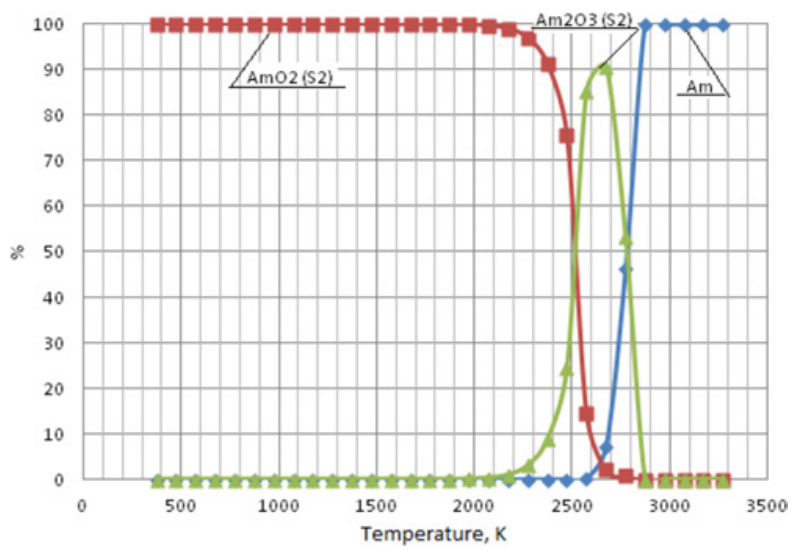

Figure 3. The distribution of Am in the incineration of radioactive graphite.

Plutonium is distributed in the following way: to a temperature of $1800 \mathrm{~K}$ prevails in the fused $\mathrm{PuO}_{2}$ (98-99 mol.\%). With increasing temperature, the content of the condensed $\mathrm{PuO}_{2}$ begins to decrease, at the same time increasing the content of gaseous $\mathrm{PuO}_{2}$. At a temperature $2400 \mathrm{~K} \mathrm{PuO}_{2}$ vapor content is $\approx 99$ mol. \%, The content of the condensed $\mathrm{PuO}_{2}$ reduced almost to 0 mole. \%.

At temperatures from 375 to $2300 \mathrm{~K}$ in the system prevails fused $\mathrm{AmO}_{2}$ (99 mol.\%). Increasing the temperature to $2700 \mathrm{~K}$ causes a rise in the content of the condensed $\mathrm{Am}_{2} \mathrm{O}_{3}$ to $90 \mathrm{~mol}$. \%, As well as vapor Am to 9 mol. $\%$ And a decrease in the amount of condensed $\mathrm{AmO}_{2}$ to 0 mole. \%. At $3300 \mathrm{~K}$ decreases the amount of condensed Am2O3 to 0 mole. \% and amount of vapor Am increases to $100 \mathrm{~mol} \%$.

As a result of thermodynamic modeling revealed that the combustion of radioactive graphite in an atmosphere of $\mathrm{O}_{2}$, americium, plutonium and europium are present in the form of oxygen compounds. Increasing the temperature above $2000 \mathrm{~K}$ lead to evaporation of these compounds.

In accordance with the above set of phase transitions and guided by numerical simulation results, the minimum set of basic reaction (equilibrium) within the individual phases and at the interface is written below.

$$
\begin{gathered}
2 \mathrm{Eu}_{2} \mathrm{O}_{3}(S)=4 \mathrm{EuO}+\mathrm{O}_{2} \\
4 \mathrm{EuOCl}(\mathrm{S})+\mathrm{O}_{2}=2 \mathrm{Eu}_{2} \mathrm{O}_{3}(\mathrm{~S})+2 \mathrm{Cl}_{2}
\end{gathered}
$$


Table 1. The coefficients in equation constants reaction.

\begin{tabular}{|c|c|c|c|c|}
\hline $\begin{array}{c}\text { Reaction's } \\
\text { number }\end{array}$ & $\begin{array}{c}\text { Temperature } \\
\text { range } \Delta \mathbf{T}_{\mathbf{i}}, \mathbf{K}\end{array}$ & $\mathbf{A}$ & $\mathbf{B}$ & $\begin{array}{c}\text { The magnitude } \\
\text { approximation } \mathbf{R}^{\mathbf{2}}\end{array}$ \\
\hline 1 & $1873-2373$ & $\begin{array}{c}- \\
348975\end{array}$ & 87,165 & 1 \\
\hline 2 & $873-1473$ & 51740 & $\begin{array}{c}- \\
47,463\end{array}$ & 0,9842 \\
\hline 3 & $1973-2473$ & $\begin{array}{c}- \\
352836\end{array}$ & 89,027 & 0,9997 \\
\hline 4 & $1873-2473$ & $\begin{array}{c}- \\
68474\end{array}$ & 18,95 & 0,9959 \\
\hline 5 & $2173-2773$ & $\begin{array}{c}- \\
100978\end{array}$ & 50,264 & 0,991 \\
\hline 6 & $2673-2873$ & $\begin{array}{c}- \\
388183\end{array}$ & 52,927 & 0,9601 \\
\hline
\end{tabular}

$$
\begin{gathered}
2 \mathrm{Eu}_{2} \mathrm{O}_{3}(\mathrm{~S})=4 \mathrm{EuO}+\mathrm{O}_{2} \\
\mathrm{PuO}_{2}(\mathrm{~S})=\mathrm{PuO}_{2} \\
4 \mathrm{AmO}_{2}(\mathrm{~S})=2 \mathrm{Am}_{2} \mathrm{O}_{3}(\mathrm{~S})+\mathrm{O}_{2} \\
2 \mathrm{Am}_{2} \mathrm{O}_{3}=4 \mathrm{Am}+3 \mathrm{O}_{2} .
\end{gathered}
$$

The dependence of the equilibrium constants of reactions (1)-(6) of the temperature is described by the equation of the form:

$$
\ln k_{i}=A+\frac{B}{T} .
$$

The numerical values of the coefficients A and B of Eq. (7) shown in Table 1.

The values of the equilibrium constants indicate that the reaction shifted towards the formation of products.

\section{Findings}

The combustion of radioactive graphite oxygen europium is in the form of condensed EuOCl (to a temperature of $1200 \mathrm{~K}$ ), the condensed $\mathrm{Eu}_{2} \mathrm{O}_{3}$ (in the temperature range 1200-2200 C) and vapor $\mathrm{EuO}$ (at temperatures above $2200 \mathrm{~K}$ ).

The combustion of radioactive graphite oxygen plutonium is in the form of condensed $\mathrm{PuO}_{2}$ (to a temperature of $2100 \mathrm{~K}$ ) and vapor $\mathrm{PuO}_{2}$ (above $2100 \mathrm{~K}$ ).

The combustion of radioactive graphite oxygen americium is in the form of condensed $\mathrm{AmO}_{2}$ (to a temperature of $2500 \mathrm{~K}$ ), the condensed $\mathrm{Am}_{2} \mathrm{O}_{3}$ (in the temperature range 2500-2900 C) and vapor Am (at temperatures above $2900 \mathrm{~K}$ ).

The findings should be considered when disposing of radioactive graphite by incineration.

\section{References}

[1] Beskorovayny NM, Kalin BA, Platonov PA Materials of construction of nuclear reactors. (Energoatomizdat, 1995)

[2] Blinova IV, Sokolov ID Atomic energy technology abroad, 6, 3 (2012) 
[3] Skachek MA Management of spent nuclear fuel and radioactive waste nuclear power station (Publishing House MEI, 2007)

[4] Barbin NM, Terentev DI, Alekseev SG, Peshkov AV. Proceedings of the International Congress "Fundamental technologies for processing and disposal of man-made waste"

[5] Kolbin TS, Terentev DI, Barbin NM, Alekseev SG. Technosphere safety, 1, 30 (2013)

[6] Kolbin TS, Terentev DI, Barbin NM, Alekseev SG. Technosphere safety, 2, 40 (2013)

[7] Yang H-C, Eun H-C, Lee D-G. J. of nuclear science and technology, 10, 869 (2005)

[8] Barbin NM, Terentev DI, Alekseev SG Chemical and Radiation Physics: Collection / Ed. IG Assovskogo, AA Berlin, GB Manelis (Torus Press, 2011)

[9] Barbin NM, Terentev DI, Alekseev SG. Modern science 2, 134 (2012)

[10] Vatolin NA, GK Moiseev, Trusov BG. Termodinamic modeling in high temperature systems. (Metallurgy, 1994)

[11] GK Moiseev, Vyatkin GP Barbin NM Application of thermodynamic modeling for the study of interactions involving ionic melts - (Chelyabinsk: Out of SUSU, 2002)

[12] Gurevich LV, Weitz IV, Medvedev VA Thermodynamic properties of individual substances: Right. ed-e in 4 volumes (Nauka, 1982)

[13] Alemasov VE, Dergalin AF, Silence AP Thermodynamic and transport properties of the combustion products: Directory in 5 volumes (VNIIT, since 1971) 